\title{
Обоснование принципиальной схемы технологического модуля в системе оригинального семеноводства картофеля
}

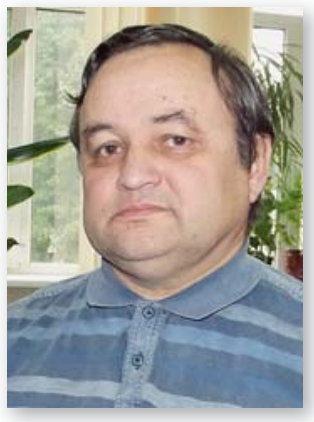

С.Н. Петухов

Приведены результаты поиска эффективных путей модернизации процесса оригинального семеноводства в направлении увеличения коэффициента размножения семенного материала на этапе выращивания миниклубней картофеля. Проведена экспериментальная отработка элементов технологии и технических параметров технологического модуля. Разработана принципиальная схема технологического модуля нового поколения.

Ключевые слова: картофель, оригинальное семеноводство, модернизация, коэффициент размножения, технические параметры, принципиальная схема.

$\Gamma$ оиск эффективных путей модернизации процесса оригинального семеноводства для увеличения коэффициента размножения семенного материала и сокращения при этом материальных, трудовых, энергетических ресурсов, уменьшения производственных затрат на этапе выращивания мини-клубней картофеля привел к необходимости создания производственного модуля нового поколения $[1,2,3]$. Результаты исследований показали, что наиболее приемлем вариант выращивания миниклубней в теплицах либо в других вегетационных сооружениях, оборудованных стеллажами в виде отдельно стоящих модулей с числом растений до 40 шт. в одном модуле [4].

Сбор мини- или микроклубней проводят по мере их нарастания до стандартного размера (при благоприятных условиях - с интервалом в один день). Оптимальный размер мини-клубней - массой 10-20 г., микроклубней - массой 3-5 г.

Элементы технологии и технических параметров технологического модуля при ускоренном размножении клубней картофеля из безвирусных микроклубней и мини-клубней отрабатывали на отдельно взятых растениях [5]. отверстия в крышке, выходят наружу, образуя при этом зеленую крону картофельного растения.

Результаты экспериментов позволили разработать технологический модуль с потенциалом размножения до 4000 клубней с одного растения в год (рис.).

Растения в модуле высаживают в две строчки с расстоянием между строк $45 \mathrm{~cm}$, расстояние между клубнями в строке $10 \mathrm{~cm}$. Всего в технологическом модуле размещается 40 клубней. При посадке клубни картофеля вдавливают в почвенный грунт до уровня их макушечной части.

Контроль над образованием сто- определить способность миниклубня картофеля самостоятельно (без механического вмешательства) прорастать из зоны клубнеобразования через слабо просвечивающиеся микроотверстия на дневную поверхность, т.е. в зону стеблеобразования;

- отработать технологию проращивания клубня в установке при полной темноте и дальнейшей фиксацией растения (при достижении длины ростков до 30 см) в крышке камеры, отделяющей зону клубнеобразования установки от зоны стеблеобразования и уточнить некоторые конструктивные элементы технологического модуля.

В опыте использовали клубни картофеля сорта Удача. После прогревания клубней до появления на них ростков их вдавили в почву зоны корнеобразования установки и в дальнейшем проращивали непосредственно в зоне клубнеобразования, затененной от попадания дневного света. При достижении длины ростков около 30 см их концы фиксировали в пластиковой панели (крышке) при помощи поролона.

В результате эксперимента было установлено, что появившиеся ростки клубней хорошо ориентируются в зоне клубнеобразования и самостоятельно находят чуть светящиеся лонов и клубней, а также периодический сбор клубней по мере их нарастания до определенных размеров - путем открытия панелей модуля. При необходимости растения досвечивают.

Заключение. Для приближения к намеченному потенциалу размножения - 4000 мини-клубней в год от одного растения требуется провести две ротации выращивания в год. Весенняя ротация - 80 микроклубней или мини-клубней с одного микрорастения. Хранение полученного урожая в холодильных камерах до завершения у клубней естественного периода покоя (3-4 месяца). Осенняя ротация - 50 мини-клубней от одного микроклубня (или мини-клубня первого поколения). После зимнего хранения и естественного снятия с клубней периода покоя, к весне следующего года для посадки в поле будет подготовлено 4000 миниклубней от каждого исходного микрорастения. Таким образом коэффициент размножения составит 1:4000 в год.

Библиографический список

1.Зернов В.Н., Пономарев А.Г., Абрамов З.Т. Развитие ианализ технологического и технического обеспечения производства мини-клубней, выращиваемых в условиях вегетационных сооружений // Инновационное развитие АПК России на базе интеллектуальных технологий: сб. науч. докл. меж- 


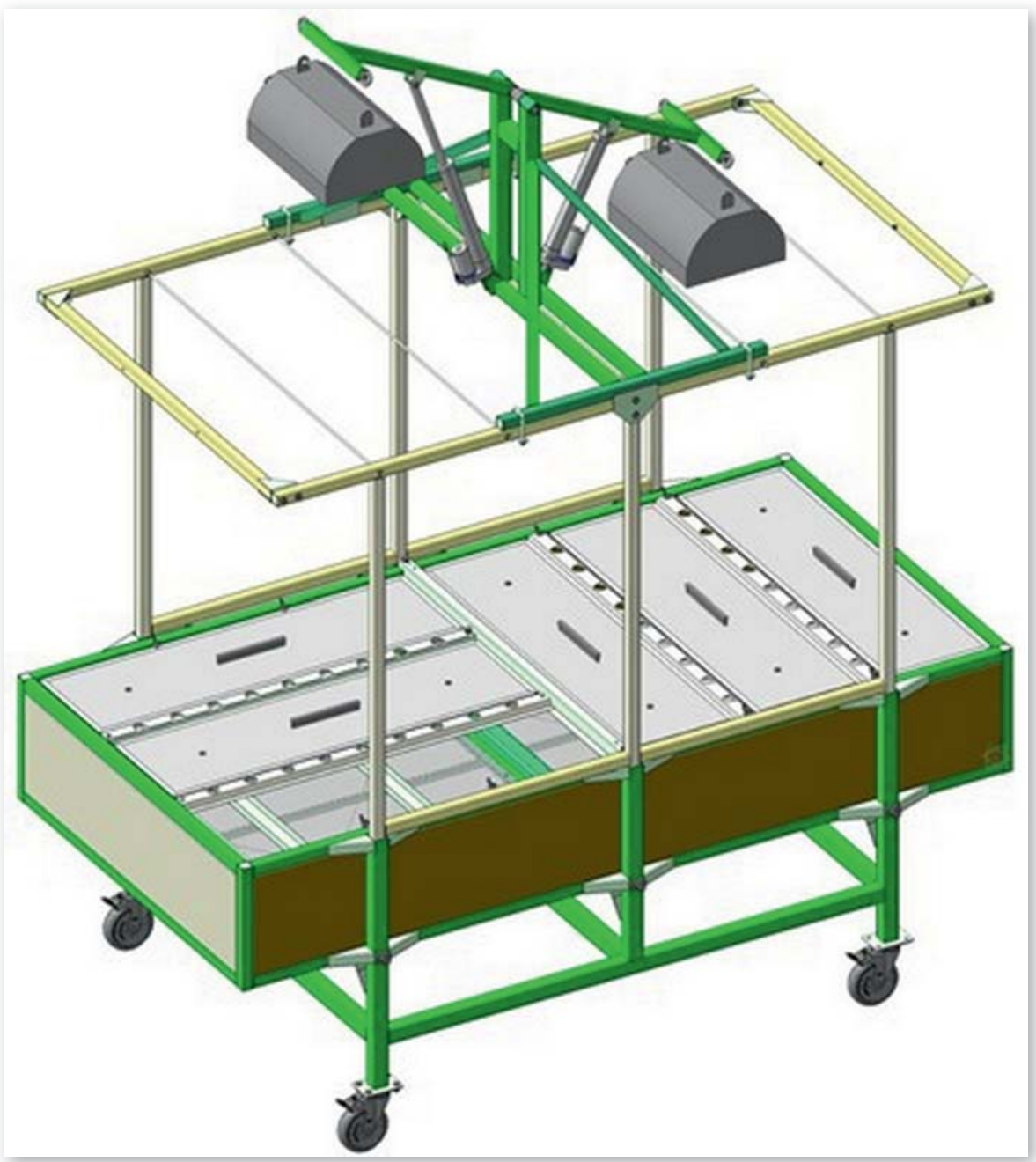

Общий вид технологического модуля для ускоренного размножения картофеля

дунар. науч.-техн. конференции. М., ВИМ, 2014. С. 149-153. 2.Зернов В.Н., Колчин Н.Н. Саморегулируемая система минерального питания на основе цеолитовых субстратов в оригинальном семеноводстве картофеля // Инновационное развитие АПК России на базе интеллектуальных машинных технологий: сб. науч. докл. международной научно-технической конференции. М. ВИМ, 2014. С. 153-155.

3.Мартиросян Ю.Ц., Мартиросян В.В., Зернов В.Н. Новые технологии в производстве оздоровленного семенного картофеля // Аграрный вопрос. 2012. № 5 (37). C. $18-19$.

4.Зернов В.Н. Классификация способов получения безвирусных мини-клубней картофеля на основе биотехнологических методов // Интеллектуальные машинные технологии и техника для реализации государственной программы развития сельского хозяйства: сб. науч. докл. международной научно-технической кон ференции. М., ВИМ, 2015. С. 245-249.

5.Колчин Н.Н., Зернов В.Н., Михеев В.В. Технологические приемы и технологии, применяемые в селекции и семеноводстве картофеля, их классификация // Интеллектуальные машинные технологии и техника для реализации Государственной программы развития сельского хозяйства: сб. науч. докл. международной научно-технической конференции. М., Вим, 2015. С. 249-252.

\section{Об авторе} modernization, a multiplication ratio, technical parametres, the basic scheme.

\section{Константин Александрович Пшеченков}

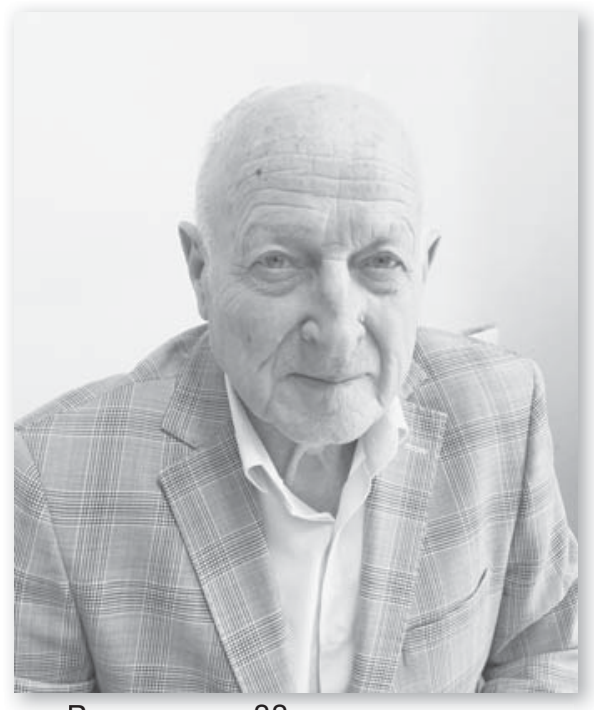

В возрасте 88 лет ушел из жизни известный ученый-картофелевод, д. т. н., профессор Константин Александрович Пшеченков.

Всю жизнь он посвятил картофелеводству. С 1 ноября 1970 года он работал в ФГБНУ ВНИИ картофельного хозяйства имени А.Г. Лорха. Константин Александрович - человек огромной работоспособности. Ему были свойственны активное творчество и новаторский подход к решению научных проблем картофелеводства. Он автор более 300 научных публикаций, 45 авторских свидетельств и патентов, в соавторстве 12 книг, в том числе: «Технология хранения картофеля», «Переработка картофеля», «Машинные технологии и техника для производства картофеля», «Комплексная механизация возделывания, уборки и хранения картофеля» и др. В последнее время он занимался проблемами хранения и переработки картофеля. Многие разработки машин и технологий производства и хранения клубней внедрены на предприятиях России и странах СНГ. За свою профессиональную жизнь Константин Александрович Пшеченков подготовил 12 кандидатов наук. Жизнь Константина Александровича - яркий пример для молодого поколения.

Ученые-картофеводы России, сотрудники ВНИИКХ имени А.Г. Лорха, редакция журнала “Картофель и овощи", ученики и коллеги выражают искренние соболезнования родным и близким Константина Александровича. 